\title{
Impact of job satisfaction on employee turnover: An empirical study of Autonomous Medical Institutions of Pakistan
}

\author{
Alamdar Hussain Khan, \\ University of the Punjab, \\ Lahore, Pakistan. \\ alamdarbaloch@ymail.com \\ Muhammad Aleem \\ University of the Punjab, \\ Lahore, Pakistan. \\ alamdarbaloch@ymail.com
}

\begin{abstract}
The Health sector in the Pakistan is facing many problems to provide the Health facilities to the masses spread over the country. The most challenging problem is the shortage of Doctor's as compared to the population. Most of the professional Doctor's prefers to serve in the abroad instead to serve in Pakistan. There are the many determinants of turnover in the Health Department. The objective of this study is to investigate the factors such as Pay, Promotion, Job Safety and Security, Nature of the Work that effect the job satisfaction level and that are the cause of turnover of employee's in the Autonomous Medical Health Institutions in the Pakistan. The factors of job satisfaction are such as Pay, Promotion, Job Safety and Security, Nature of the Work. The sample of the research is consist of 200 doctors, nurses, administrative and accounts staff working in Autonomous Medical Health institutions in the Punjab. Out of total 270 Questionnaires distributed in the Autonomous Medical Institutions of the Punjab 200 were received back and used for analysis. For data analysis/results the SPSS 20.0 is used.
\end{abstract}

Key words: Turnover, job satisfaction, Medical Institutions, Pakistan, doctors

JEL Classification: J63, J28

\section{INTRODUCTION}

In the organization the Human Resources are the life blood of life. It is difficult for the organization to compete in the current era of competition without the loyal and competent Human Resource. The loyal employees are the most productive and a source for the development of the organization and vice versa. It becomes challenge for the Human Resource Managers to retain the employees for long period and to minimize the turnover in the organization. The high turnover of employees in the organization increases the cost 
of hiring new workforce and decrease the productively. An organization can gain the competitive advantage due to retaining of qualified, productive and loyal work force. The turnover is the most focused area by the scholars, academicians, researchers and the human resource managers. The employee retention is also considered the input for improving the financial performance of the organization (Raikes \& Vernier 2004). The outcome of the increased level of turnover in the organization is also in the form of indirect cost like burden on the existing workforce, loss of social capital and low morale. (Des \& Shaw 2001).

The increasing trend of turnover enhances the cost and reduces the productivity and efficiency of the organization. Hence, it is crucial to study the factors affecting the turnover in the organizations.

For the opulence of the organization the human resource management becomes a momentous aspect for the organization. These are the human who are the foundation for the development and achieving the objectives of the organization. In this modern age, human are considered the most precious assets that impact on the performance. (Kabene et al, 2006). In the health sector, doctors are the most valuable assets and prominent role for the achieving the government objective to provide the maximum health facilities to the public. .Like other assets, human assets requires the proper management. Hence without the developed system of human resource, it is difficult to manage and retained the doctors.

There is the emerging issue in Pakistan is the doctor's strikes against the government in the hospitals that their demands are not fulfilled. The young doctor's protests also affect the patients in the hospitals. Due to the absence of the doctors, $60 \%$ clinics and hospitals were shut down and resultantly 500 patients were expired. (Kazmi,2011). Moreover again on 16th April 2012, there was strike in the hospitals and demanded the service structure from the government. As per daily-times newspaper 2 July 2012, there is the service structure for the doctors but is not implemented with letter and spirit which requires improvement according to Masood sheikh. With the proper implementation of the service structure 13000 doctors awaited from the last 16 to 20 years will be promoted in the next grade. Hence, this is the most crucial issue and requires the government attention as the government has to provide the health facilities to the public. The patients are only treated by the doctors and there is no alternative available. (FRANKLIN, 2006). The employee turnover, absentism, is the outcome of the job dissatisfaction. The employee job satisfaction is very vital for the organization to retain the employees for the longer period.

The objective of this paper is to find out the factors like Pay, Promotion, Job Safety and Security, Nature of the Work that effect the level of job satisfaction. Furthermore the effect of job satisfaction on turnover of Medical Sector employees from Pakistan to abroad and retaining the employees for the longer period in the Department.

\section{LITERATURE REVIEW}

In this section the factors affecting the turnover in the organization are explained.

\section{Impact of Rewards/pay on Job satisfaction and Employee Turnover}

The scholars studied the public sector managers to find out the determinants of job satisfaction and it was concluded that the job satisfaction level of a employee is significantly effected by the compensation practices in the organization (Sokoya 2000). 
Opkara (2002) in the study found that there are the certain factors that influence the level of job satisfaction of the employee. These are the compensation, promotion opportunities, the work itself, relationships with co-workers and the supervision. The pay was considered the dominant factor in measuring the job satisfaction of employee. Similarly another study was conducted by the Frye (2004) and it was concluded that the compensation is the most critical factor for the organizations to magnetize the right workforce and retain them for the long period of time. In addition to that the compensation is positively correlated with the job satisfaction of a employee in the organization. Another study was also conducted that to found the effect of pay on the job satisfaction and it was concluded that the there is positive relationship between job satisfaction and pay (Nguyen et al. 2003)

It was found that the lower level of compensation is the cause of employee turnover (Abassi and Hollman 2000). The study also concluded that improper recruitment, bad working conditions, less compensation has negative effect on the employee turnover (Milman 2002). Furthermore the job satisfaction increases with better pay and fringe benefits and decreases the turnover of the employees (Beilock and Capelle 1990). In the context of Literature Review we Hypothesis:

H1: Pay is positively correlated with the job satisfaction.

H2: Pay is negatively correlated with the employee turnover.

\section{Impact of Promotion on Job satisfaction and Employee Turnover}

The scholars investigated the relationship of jobs satisfaction with demographic determinants as well as the other factors like job autonomy, leadership behavior and promotion system. I was concluded that the factors significantly affect the job satisfaction of employees (Dawson, 1987). Furthermore the Nguyen, Taylor, \& Bradley (2003) also found the satisfaction level of employee is affected with existence of promotion opportunities in the organization.

An organization to retain its workforce for a long period of time has to make investment for the career advancement of Human Resource. (Hall \& Moss, 1998; Hsu, Jiang, Klein \& Tang, 2003; Steel et al., 2002; Woodruffe, 1999). The absence of promotion and training opportunities is the cause for the talented employees to quit the organization. Due to high ratio of turnover the career growth in such organization are decreased. (Shore \& Griffeth, 2003; Steel et al., 2002). The organizations require the brilliant workforce to get the competitive advantage and employees want to grow and develop their career. (Prince, 2005). In the light of previous research we hypothesis that:

\section{H3: Promotion is positively correlated with the job satisfaction.}

H4: Promotion is negatively correlated with the employee turnover.

\section{Impact of Working Conditions on Job satisfaction and Employee Turnover}

Hytter (2008) explained that the work environment is considered in the context of industrial environment like clamor, lifts etc. The attributes of work environment are different in the service sector as compared to industrial sector as it deals with the clients (Normann 1986). The working environment is considered the most significant factor of job satisfaction. (Spector 2008). The other researcher in their study found that work environment is also a superior predictor of employee job satisfaction in the organization setting (Reiner and Zhao, 1999; Carlan, 2007; Ellickson and Logsdon, 2001; Forsyth and Copes, 1994). Moreover 
variation exists in terms of pay packages, working conditions, incentives, recognition and fringe benefits for the employees (Lavy, 2007). In the past studies it was found by the scholars that there are numerous factors are crucial in retaining the workforce. These are like work life balance, work environment and career opportunities (Cappelli 2000:104). The Literature Review thus supported the hypothesis as under:

It supports the following hypothesis:

H5: The working conditions are positively correlated with the job satisfaction.

H6: The working conditions are negatively correlated with the employee turnover.

\section{Impact of Nature of work on Job satisfaction and Employee Turnover}

The other important determinant of turnover is the nature of work. The focus on it has been amplified due to increase in the level of education in the country. Before this much attention was not given on it due to low level of awareness, education. The researchers found in their studies that the work has effect the turnover intention and satisfaction level of employees in the organization settings. Ting (1997) Locke (1995) found the significant relationship of job satisfaction and turnover. Robbins et al. (2003, p. 77) refer to the work itself as "the extent to which the job provides the individual with stimulating tasks, opportunities for learning and personal growth, and the chance to be responsible and accountable for results." The work that related to the aptitude of employees is most fascinated for them. (Robbins,1993). It was found during the study of clerical employees in the banking sector that the turnover intention has negative correlated with nature of work (Koh and Goh 1995). In the Light of above supplement we Hypothesis as under:

H7: The Nature of work is positively correlated with the job satisfaction.

H8: The Nature of work is negatively correlated with the employee turnover.

\section{Impact of Job satisfaction on Employee Turnover}

In the Literature, the turnover topic is studied to find out the relationship it with job satisfaction. Most of the researchers found the negative association between job satisfaction and turnover. (e.g., Cotton \& Tuttle, 1986; Arnold \& Feldman, 1982; Bluedorn, 1982; Mobley, 1982; Price, 1977, and many others),

The job satisfaction is the critical factor in delivering the quality products/services and $s$ ultimately for the success of the company (Silva 2006). The researchers found that job satisfaction is significant towards the turnover and absenteeism. (Koh, and Boo, 2004; Lee and Liu, 2007). Hence the Literature ropes to devise the following Hypothesis

H9: Job Satisfaction is negatively correlated with the employee turnover. 


\section{Theoretical Frame Work}

In the light of the aforesaid literature review we can develop the following theoretical framework:

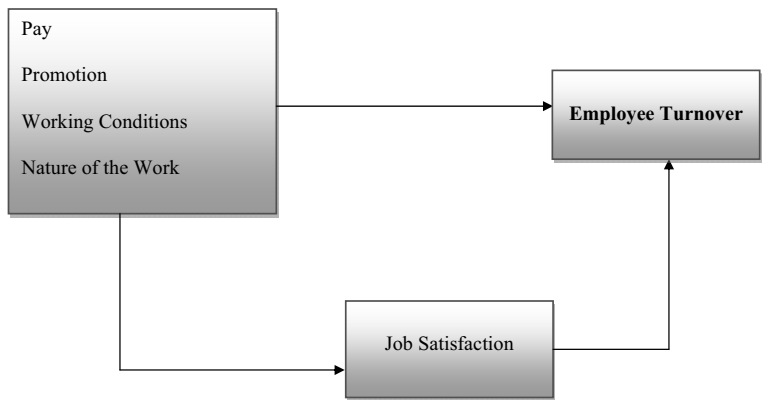

Fig. 1. Theoretical Frame Work

\section{METHODOLOGY}

The study examines the relationship of the factors such as Pay, Promotion, Job Safety and Security, Nature of Work on job satisfaction and employee turnover. The data was gathered from 200 Doctors, Nurses, Administrative and Accounts \& Finance staff from Basic Pay Scale 7-19 of Autonomous Medical Institution of the Punjab. The statistical technique of convenient sampling was used to collect the data from the target population. The questionnaires were send to the target population i.e. AMI's of Punjab and received back by hand or mail.

\section{Instrument}

The questionnaire was divided into two sections; the first section pertained to the questions of independent variables i.e. pay, promotion, job safety and security, working conditions, relationship with supervisor, nature of work mediating variable job satisfaction and dependent variable turnover.

The second section was about the demographic factors like age, designation, education, experience, gender, job relevancy and nature of job. The alpha range was found .901 that is ample. To get the response from the target population the Likert scale was used demonstrating a score of 1 for strongly disagree, 2 for disagree, 3 for undecided, 4 for agree and 5 for strongly agree.

\section{Data analysis procedure}

Many scholars are the view that statistical packages are the most reliable instruments to get the precise and inclusive results on the large scale. (Buglear, 2005). Due to reliability and accuracy most of the scholars in their research has used the statistical packages like SPSS. In the current study to find out the results of data, the SPSS with 20 versions is used. (version 11 was used by Okpara, 2004). 


\section{RESULTS AND FINDINGS}

\section{Response rate}

In the Autonomous Medical Institution's of the Punjab 250 questionnaires were distributed and 200 were received back. The $80 \%$ response was received from the target sample.

\section{Demographics frequency table}

The information regarding the demographics are elaborated in the given below table.

Table 1

\begin{tabular}{|c|c|c|c|}
\hline \multicolumn{2}{|c|}{ Description } & \multirow{2}{*}{$\begin{array}{c}\text { Frequency } \\
9\end{array}$} & \multirow{2}{*}{$\frac{\text { \%age }}{4.5}$} \\
\hline Age & $18-24$ & & \\
\hline & $25-31$ & 66 & 33.0 \\
\hline & $32-38$ & 47 & 23.5 \\
\hline & $39-45$ & 33 & 16.5 \\
\hline & $46-52$ & 31 & 15.5 \\
\hline & Above 52 & 14 & 7.0 \\
\hline \multirow[t]{2}{*}{ Gender } & Male & 138 & 69.0 \\
\hline & Female & 62 & 31.0 \\
\hline \multirow[t]{5}{*}{ Qualification } & Matriculation & 11 & 5.5 \\
\hline & Intermediate & 33 & 16.5 \\
\hline & Graduation & 52 & 26 \\
\hline & Master & 92 & 46 \\
\hline & M.Phil / Phd & 12 & 6 \\
\hline \multirow[t]{3}{*}{ Job Level } & BPS 7-16 & 94 & 47 \\
\hline & BPS $17-18$ & 92 & 46 \\
\hline & Above 18 & 14 & 7.0 \\
\hline \multirow[t]{5}{*}{ Organizational Tenure } & $1-5$ & 67 & 33.5 \\
\hline & $6-10$ & 50 & 25.0 \\
\hline & $11-15$ & 28 & 14.0 \\
\hline & $16-20$ & 17 & 8.5 \\
\hline & Above 20 & 38 & 19.0 \\
\hline \multirow[t]{3}{*}{ Nature of Employment } & Contract & 39 & 19.5 \\
\hline & Permanent & 137 & 68.5 \\
\hline & Ad hock/other & 24 & 12.0 \\
\hline
\end{tabular}

Source: own calculation

The questionnaire consists of mixture of the respondents included in the demographic section. In the sample most of the employee's age range is $25-31$ years. These employees have the less tenure in the service as the minimum age to quality the Public Sector job in Pakistan is 18 years. The satisfaction level in these employees is less as compared to the employees has the more years in the employment. The other brackets of age are also included in the sample. In the Pakistan there is not much trend of female employment in the labour market as in the sample there is majority of male. The major portion in the sample consist of Master Degree holders because the sample consist of doctors, paramedics, accounts and admin staff and most 
of the them have the master qualification. In the Public Sector of Pakistan, the compensation paid to the employees range in BPS 7-16 is less as compared the employees of BPS 17 to onward. The employees of BPS 7-16 cover the maximum portion of sample as the turnover ratio of these employees is higher as compared to employees in BPS 17 and above. The intention to leave the job in employee's has less tenure is higher as compared to employee's has more tenure in the Department. The major portion of the sample covers the employees having the tenure of 1-5 years. The maximum employees are recruited on permanent basis in the Health Department; hence the $68.5 \%$ in the sample are permanent employees.

The job satisfaction is the mediation factor under the reference study and the method of Judd and Kenny (1981) and Baron \& Kenny (1986) has been adopted. For the analysis of the data we have used three equations. The exogenous variables in the model such as Pay, Promotion, Working Conditions and Nature of Work were regressed on the mediating variable i.e. Job Satisfaction in the Equation No.01. Then the regression of the exogenous variables on the endogenous variable employee turnover was performed in the Equation No. 02. The exogenous variables Pay, Promotion, Working Conditions and Nature of Work and mediating variable Job Satisfaction are also regressed on the endogenous variable Employee Turnover in the Equation No. 03. The output of the three equations is elaborated in the Table-II.

Table 2

Regression equations of exogenous variables and mediation variable job satisfaction and the endogenous variable employee turnover.

\begin{tabular}{|c|c|c|c|c|c|c|}
\hline Eqn. & Dependent variable & Independent variable & Beta & $\mathrm{T}$ & R-Square & $\mathrm{F}$ \\
\hline $\begin{array}{l}1 \mathrm{a} \\
1 \mathrm{~b} \\
1 \mathrm{c} \\
1 \mathrm{~d}\end{array}$ & $\begin{array}{l}\text { Job Satisfaction } \\
\text { Job Satisfaction } \\
\text { Job Satisfaction } \\
\text { Job Satisfaction } \\
\end{array}$ & $\begin{array}{l}\text { Pay } \\
\text { Promotion } \\
\text { Working Conditions } \\
\text { Nature of work } \\
\end{array}$ & $\begin{array}{l}.250 \\
.236 \\
.288 \\
.243\end{array}$ & $\begin{array}{l}3.639 \\
3.424 \\
4.238 \\
3.527 \\
\end{array}$ & $\begin{array}{l}.063 \\
.056 \\
.083 \\
.059\end{array}$ & $\begin{array}{l}13.243 \\
11.726 \\
17.962 \\
12.443\end{array}$ \\
\hline $\begin{array}{l}2 \mathrm{a} \\
2 \mathrm{~b} \\
2 \mathrm{c} \\
2 \mathrm{~d}\end{array}$ & $\begin{array}{l}\text { Employee Turnover } \\
\text { Employee Turnover } \\
\text { Employee Turnover } \\
\text { Employee Turnover }\end{array}$ & $\begin{array}{l}\text { Pay } \\
\text { Promotion } \\
\text { Working Conditions } \\
\text { Nature of Work }\end{array}$ & $\begin{array}{l}-.027 \\
-.111 \\
-.147 \\
-.215\end{array}$ & $\begin{array}{r}-.373 \\
-1.571 \\
-2.090 \\
-3.092\end{array}$ & $\begin{array}{l}.001 \\
.012 \\
.022 \\
.046\end{array}$ & $\begin{array}{r}.139 \\
2.469 \\
4.368 \\
9.52\end{array}$ \\
\hline $3 \mathrm{a}$ & Employee Turnover & Pay & -.010 & -1.34 & .005 & .483 \\
\hline & & Job Satisfaction & -.067 & -.909 & & \\
\hline $3 b$ & Employee Turnover & $\begin{array}{l}\text { Promotion } \\
\text { Job Satisfaction }\end{array}$ & $\begin{array}{l}-.100 \\
-.045\end{array}$ & $\begin{array}{r}-1.377 \\
-.625\end{array}$ & .014 & 1.426 \\
\hline $3 \mathrm{c}$ & Employee Turnover & $\begin{array}{l}\text { Working Conditions } \\
\text { Job satisfaction }\end{array}$ & $\begin{array}{l}-.138 \\
-.029\end{array}$ & $\begin{array}{r}-1.882 \\
-.397\end{array}$ & .022 & 2.254 \\
\hline $3 d$ & Employee Turnover & $\begin{array}{l}\text { Nature of Work } \\
\text { Job Satisfaction }\end{array}$ & $\begin{array}{l}-.210 \\
-.018\end{array}$ & $\begin{array}{r}-2.931 \\
-.252\end{array}$ & 0.046 & 4.790 \\
\hline
\end{tabular}

Source: own calculation

To find out that the job satisfaction is the mediating variable and has its significance with the Pay, Promotion, Working conditions, Nature of the Work and the Employee Turnover in the Autonomous Institutions of the Health Department we have performed the regression analysis in the equation 1a, 2a and 3a.

To investigate the effect of exogenous variables on the mediation variable job satisfaction the regression of equation No. 1a was used and found that the level of job satisfaction is affected by the Pay, Promotion, Working Conditions, Nature of the Work. Moreover the results of the exogenous variables on the endogenous variable Employee Turnover were also found significant as predicted in the equation $2 \mathrm{a}$. At the end in the equation 3a the relationship of Employee Turnover with the mediating variable job satisfaction and 
exogenous variables was also concluded and found that the job satisfaction is the mediating variable. As the beta of pay is .250 in the equation 1a and decreased in the equation 2a with -.147 and 3a with -0.010. The said equations results stated that the job satisfaction is the mediating variable in such case and the employee with the low level of job satisfaction resulted into the increase in the rate of employee turnover.

We have regressed the Employee Turnover on the independent variables and the mediating variable job satisfaction. The results indicate that the Beta in the equation 2(a) was -.147 and in the equation 1(a) was .250. It predicts that the job satisfaction is the mediating variable in this model.

\section{CONCLUSION AND RECOMMENDATIONS}

The said study pertained to the employees of the Autonomous Medical Institutions of Health Department in the Province of Punjab in order to find out the factor affecting the job satisfaction level and the impact of job satisfaction on the employee turnover. The findings suggested that the variables like Pay, Promotion, Working Conditions and Nature of Work are the prominent for the job satisfaction level of the employees. The management of the Autonomous Medical Institutions may take the appropriate steps to enhance the job satisfaction level of employees. Furthermore it is suggested management should take into the account of the factors such as Pay, Promotion, Working Conditions and Nature of Work in order to minimize the turnover level of the employees in the Autonomous Medical Institutions.

\section{Limitation and future directions of the study}

We have conducted the research by taking the variables Pay, Promotion, Working Conditions and Nature of Work in this study. In order to more general results, the other factors may also be included in the future research. The sample size was also limited that can also be increased to find out other determinants. A comparative study of public and private hospitals may also be conducted to find out the differences in both sectors.

\section{REFERENCES}

Abassi, S. M. and Hollman, K. W. (2000), Turnover: the real bottom line, Public Personnel Management, 2(3), pp. 33342.

Abegglen, J.C. (1958), The Japanese Factory: Aspects of Its Social Organization, Free Press, Glencoe, IL.

Alfonso Sousa-Pozaa, Andre's A. Sousa-Pozab (2000), Journal of Socio-Economics, 29, pp. 517-538.

Arnold, H.J. and Feldman, D.C. (1982), A multivariate analysis of the determinants of job turnover, Journal of Applied Psychology, 67(3), pp. 350-360.

Autry, C.W., and Daugherty, P.J. (2003), Warehouse operations employee: linking person-organization fit, job satisfaction, and coping response, Journal of Business Logistics, Vol. 24, No. 1, pp. 171-197.

Baron, R. M., \& Kenny, D. A. (1986), The moderator-mediator variable distinction in social psychological research: Conceptual, strategic and statistical considerations, Journal of Personality and Social Psychology, 51, pp. 1173-1182.

Beilock, R. and Capelle, R.B. Jr (1990), Occupational loyalties among truck drivers, Transportation Journal, Vol. 29, No. 2, pp. 20-28.

Bell, J. (2007), Doing your research project, New York: McGraw-Hill Education.

Bolt, J.F. (1983), Job security: its time has come, Harvard Business Review, Vol. 61, No. 6, pp. 115-23.

Bluedorn, A.C. (1982), A unified model of turnover from organizations, Human Relations, 35(2), pp. 135-153. 
Borstorff, P. C., \& Marker, M.B. (2007), Turnover Drivers and Retention Factors Affecting Hourly Workers: What is Important? Management Review: An International Journal, 2(1), pp. 14-27.

Brunetto, Y., \& Farr-Wharton, R. (2002), Using social identity theory to explain the job satisfaction of public sector employees, The international journal of public sector management, 15 (7), pp. 534-551.

Buglear, J. (2005), Quantitative methods for business: The A-Z of QM, London: Butterworth Heinemann.

Cappelli, P. (2000), A Market-Driven Approach to Retaining Talent, Harvard Business Review, 78(1), pp. 103-112.

Carlan, P. (2007), The search for job satisfaction: a survey of Alabama policing, American Journal of Criminal Justice, Vol. 32, No. 1-2, pp. 74-86.

Cambell, A., Converse, P., Rogers, W. (1976), The Quality of American Life, Russell Sage, New York, NY.

Cavana, R. Y., Delahaye, B. L., \&Sekaran, U. (2001), Applied business research: Quantitative and qualitative, Australia: John Willey and Sons.

Chiu, C. (1998), Do professional women have lower job satisfaction than professional men? Lawyers as a case study [Electronic version], Sex roles, 38, (7/8), pp. 521-537.

Cotton, J. L. and Tuttle, J. F. (1986), Employee turnover: A meta-analysis and review with implications for research, Academy of Management Review, 11(1), pp. 55-70.

Debrah, Y. (1993), Strategies for coping with employee retention problems in small and medium enterprises (SMEs) in Singapore, Entrepreneurship, Innovation, and Change, 2, pp. 143-172.

Dess, G. D, Shaw, J. D. (2001), Voluntary turnover, social capital, and organizational performance, Academy of Management Review, 26 (3), pp. 446-56.

Dotan, H. (2007), Friendship ties at work: Origins, evolution and consequences for managerial effectiveness (Unpublished doctoral dissertation), University of California, Los Angeles, CA.

Fine, G. (1986), Friendship in the workplace, In V.J. Derlega, and B.A. Winstead (Eds.) Friendship and social interaction (pp. 185-206), New York, NY: Springer-Verlag.

Ellickson, M. and Logsdon, K. (2001), Determinants of job satisfaction of municipal government employees, State Local Government Review, Vol. 33, No. 3, pp. 173-84.

Forsyth, C. J. and Copes, J. H. (1994), Determinants of job satisfaction among police officers, International Review of Modern Sociology, Vol. 24, No. 1, pp. 109-16.

Frye, M. B. (2004), Equity-based compensation for employees: firm performance and determinants, The Journal of Financial Research, 27(1), pp. 31-54.

Guest, D. E. (2004), Flexible employment contracts, the psychological contract and employee outcomes: an analysis and review of the evidence, Int. J. Manage. Rev., 5/6 (1), pp. 1-19.

Hall, D. T., \& Moss, J. E. (1998), The new protean career contract Helping organizations and employees adapt, Organisational Dynamics, 26(3), pp. 22-37.

Hamilton, E. A. (2007), Firm friendship: Examining functions and outcomes of workplace friendship among law firm associates (Unpublished doctoral dissertation), Boston College, Boston, MA.

Hsu, M. K., Jiang, J. J., Klein, G., \& Tang, Z. (2003), Perceived career incentives and intent to leave, Information \& Management, 40, pp. 361-369.

Hytter, A. (2008), Dark Side Leaders, Work Environment and Employee Health. Retrieved from Växjö University, Studies in Leadership, Entrepreneurship, and Organization, Website: hvxu.se/ehv/forskning/hofreseminarier/2008/080514\%20DarkSide\%20Final\%20version.pdf

James, D. (1996), Forget Downsizing, Now It’s Participative Redesign, Bus. Rev. Weekly, 18(46), pp. 70-72.

Judd, C. M., \& Kenny, D. A. (1981), Process analysis: Estimating mediation in treatment evaluations. Evaluation Review, 5, pp. 602-619.

Kazmi, A. (2011), Doctors strike-A result of rage or corruption? Retrieved on July 09, 2011 from http://insider.pk/ national/health/doctors-strike-in-pakistan/ 
Koh, H. C. and Boo, H. Y. (2004), Organizational ethics and employee satisfaction and commitment, Management Decision, Vol. 42, No. 5, pp. 677-693.

Lavy, V. (2007), Using performance based pay to improve the quality of teachers, The Future of Children, Vol. 17, No. 1, pp. 87-109.

Lee, C. Y., and Liu, C. H. (2007), An examination of factors affecting repatriates' turnover intentions, International Journal of manpower, Vol. 28, No. 2, pp. 122-134.

Locke, E. A. (1995), Commentary: The micro-analysis of job satisfaction: Comments on Taber and Alliger [Electronic version], Journal of Organizational Behavior, 16(2), pp. 123-126.

Milman, A. (2002), Hourly employee retention in the attraction industry: research from small and medium-size facilities in Orlando, Florida, Journal of Leisure Property, Vol. 2, pp. 40-51.

Mobley, W. H., Griffeth, R. W., Hand, H. H. and Meglino, B. M. (1979), Review and conceptual analysis of the employee turnover process, Psychological Bulletin, 86, pp. 493-522.

Mooney, M. (1984), Let's use job security as a productivity builder, Personnel Administrator, Vol. 29, No. 1, pp. 38-44.

Morris, T., Lydka, H. and O'Creevy, M.F. (1993), Can commitment be managed? A longitudinal analysis of employee commitment and human resource policies, Human Resource Management Journal, Vol. 3, No. 3, pp. 21-42.

Morrison, R. (2004), Informal relationships in the workplace: Associations with job satisfaction, organisational commitment and turnover intentions, New Zealand Journal of Psychology, 33, pp. 114-128.

Nguyen, A., Taylor, J., Bradley, S. (2003), Relative Pay and Job Satisfaction: Some New Evidence, MPRA Paper No 1382.

Dawson, P. (1987), Computer Technology and the Job of the First-line Supervisor New Technology, Work Employment, 2(1), pp. 47-59.

Normann, R. (1986), Service Management. Strategy and Leadership in Service Business, Chichester: Wiley.

Okpara, J. O. (2004), Personal characteristics as predictors of job satisfaction; An exploratory study of IT managers in a developing economy, Information technology and people, 17 (3), pp. 327-338.

Padilla-Velez, D. (1993), Job satisfaction of vocational teachers in Puerto Rico. The Ohio State University.

Price, J. L. (1977), The study of turnover, Ames, IA: Iowa State University Press.

Prince, B. J. (2005), Career-focused employee transfer processes, Career Development International, 10(4), pp. 293-309.

Reiner, M. D. and Zhao, J. (1999), The determinants of job satisfaction among United States Air Force's security police, Review of Public Personnel Administration, Vol. 19, No. 3, pp. 5-18.

Riordan, C.M., \& Griffeth, R.W. (1995), The opportunity for friendship in the workplace: An underexplored construct, Journal of Business and Psychology, 10, pp. 141-154.

Robbins, S. P., Odendaal, A., \& Roodt, G. (2003), Organizational behavior (9th ed.), Cape Town: Prentice-Hall International.

Rosenblatt, Z. and Ruvio, A. (1996), A test of a multidimensional model of job insecurity: the case of Israeli teachers, Journal of Organizational Behavior, Vol. 17, pp. 587-605.

Rosow, J. M., and Zager, R. (1985), The case for employment security, Across the Board, Vol. 22, pp. 34-41.

Ross, J. A. (1997), Does friendship improve job performance? Harvard Business Review, 75, pp. 8-9.

Shore, L. M., \& Coyle-Shapiro, J. A. M. (Ed) (2003), New developments in the employee organization relationship, Journal of Organizational Behavior, 24, pp. 443-450.

Sias, P.M., \& Cahill, D.J. (1998), From coworkers to friends: The development of peer friendships in workplace, Western Journal of Communication, 62, pp. 273-299.

Silla, I., Gracia, F., Peiró, J.M. (2005), Job insecurity and health-related outcomes among different types of temporary workers, Eco, Ind.Democracy, 26, pp. 89-117.

Silva, P. (2006), Effects of disposition on hospitality employee job satisfaction and commitment, International journal of contemporary hospitality management, Vol. 18, No. 4, pp. 317-328. 
Smith, P.C., Kendall, L.M. and Hulin, C.L. (1969), The Measurement of Satisfaction in Work and Retirement: A Strategy for the Study of Attitudes, Rand McNally, Oxford.

Sokoya, S. K. (2000), Personal Predictors of Job Satisfaction for the Public Sector Manager: Implications for Management Practice and Development in a Developing Economy, Journal of Business in Developing Nations, available at www.rh.edu/Ismt/jbdnv40.htm.

Spector, P. (2008), Industrial and Organizational Psychology: Research and Practice, 5th ed., John Wiley \& Sons, New York, NY.

Yen, T.-H., \& McKinney, W. R. (1992), The relationship between compensation satisfaction and job characteristics: A comparative study of public and private leisure service professionals, Journal of park and recreational administration, 10 (4), pp. 15-36. 